\title{
Analysis of the electric motor and transmission for a 4x4 ATV
}

\author{
Kirill Evseev*, Alexey Dyakov, and Ksenia Popova \\ Bauman Moscow State Technical University, 5/1, 2-ya Baumanskaya street, Moscow, 105005, Russia
}

\begin{abstract}
The article presents the results of a comparative tests and mathematical modeling for the selection of various units and assemblies of motor vehicles. These results were analyzed for optimal power plant and transmission selection, followed by improvements to develop a vehicle with an up to date electromechanical transmission. The article substantiates the choice of components and assemblies for a $4 \times 4$ ATV with an electromechanical transmission.
\end{abstract}

\section{Description of the developed all-terrain vehicle (ATV)}

Many works have been devoted to the creation of the technical appearance of all-terrain vehicles and the selection of its components. [1-17] Currently, there is a tendency to switch to environmentally friendly alternative methods of generating electrical energy, one of which is the electric motor. Unfortunately, now, ATVs with an electric motor are inferior to ATVs with internal combustion engines in terms of various performance characteristics. Although the former have a number of advantages over the latter: the absence of emissions, which makes it possible to improve the ecological state of the planet, and an almost silent operation mode, which makes it possible to use them during special operations, as well as for walks in natural protected areas. As a rule, during development work, it is necessary to make changes in the design of the mechanical part of the transmission, i.e. replace the mechanical transmission with an electromechanical one in order to reduce the required engine power and, as a result, reduce the cost.

In order to create an ATV with an electromechanical transmission, the characteristics of which will not be inferior to those of an ATV with a mechanical transmission, it is necessary to select the optimal power plant and transmission. In this regard, comparative tests of the available samples of motor vehicles were carried out and their mathematical model was built considering various loaded modes and operating conditions. For the all-terrain vehicle being developed, it is necessary to justify the choice of the following main components that make up the power plant:

- Traction electric motor - an electric motor designed to propel vehicles by converting electrical energy stored in storage devices into mechanical energy.

- Power converter - an element with which a regulating effect is exerted on the electric drive.

*Corresponding author: kb_evseev@bmstu.ru 
- Energy storage device - a device that absorbs, conserves and releases energy for its further use without transformations.

- Traction electric drive cooling system.

For the transmission of a being developed all-terrain vehicle, it is necessary to justify the adopted design solutions for the following newly developed components:

- Transfer case - a transmission unit of a wheeled vehicle designed to separate the power flow and distribute it between the driving axles.

- Final drive - a transmission mechanism that converts torque. It is located in front of the drive wheels of a wheeled vehicle.

\section{Analysis and justification of the choice of components of the traction electric drive}

\subsection{Traction motor}

While choosing a traction motor, a comparative analysis of the models on the market was carried out. The technical characteristics of the considered electric motors are presented in table 1 .

Based on the results of a comparative analysis of electric motor and traction calculation, the EMRAX 208 electric motor was selected. [18] The selected electric motor, with its small dimensions and weight, has high developed power and torque values, therefore, the use of the EMRAX 208 electric motor as a traction motor for an ATV is the most preferable. The EMRAX 208 electric motor is shown in Figure 1.
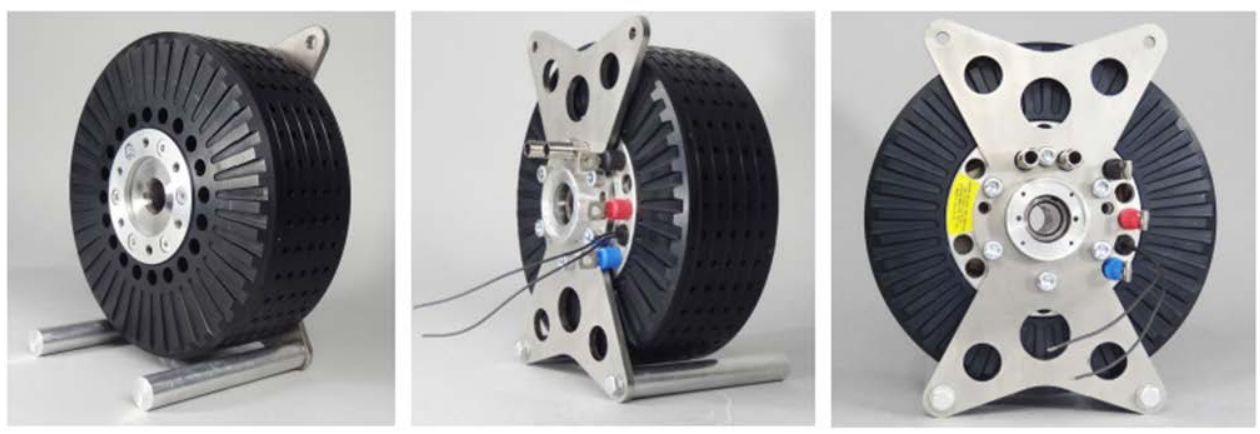

Fig. 1. View of the electric motor EMRAX 208

\subsection{Power converter}

The emDrive 500 [19] recommended by the manufacturer of the selected EMRAX 208 electric motor for joint operation as part of the traction electric drive system was chosen as the power converter used on the developed $4 \times 4$ all-terrain vehicle. A general view of the selected power converter is shown in Figure 2. 
Table 1. Technical characteristics of the considered electric motor

\begin{tabular}{|c|c|c|c|c|c|c|c|c|c|c|c|}
\hline № & Name & $\begin{array}{c}\text { HSM20 } \\
-96 \mathrm{~V}\end{array}$ & $\begin{array}{c}\text { Emrax } \\
228\end{array}$ & $\begin{array}{c}\text { Emrax } \\
208\end{array}$ & $\begin{array}{c}\text { PMS12 } \\
0 \mathrm{~W}\end{array}$ & $\begin{array}{c}\text { PMS15 } \\
6 \mathrm{~W}\end{array}$ & $\begin{array}{c}\text { Yasa } \\
\text { P400s }\end{array}$ & $\begin{array}{l}\text { Lihao } \\
260-J\end{array}$ & $\begin{array}{l}\text { Lihao } \\
262-J\end{array}$ & $\begin{array}{c}\text { UQM } \\
\text { PP100 }\end{array}$ & $\begin{array}{l}\text { Golden- } \\
\text { motor } \\
\text { HPM- } \\
20 \mathrm{KW}\end{array}$ \\
\hline 1 & Appearance & (i) & (6) & 4 & & & (.) & (6) & (5a) & tom & \\
\hline 2 & Diameter, $\mathrm{mm}$ & 249 & 228 & 208 & 254 & 304 & 305 & 290 & 290 & $\mathrm{n} / \mathrm{a}$ & 280 \\
\hline 3 & Length, mm & 237 & 85 & 85 & 172 & 213 & 80 & 280 & 369 & $\mathrm{n} / \mathrm{a}$ & 268 \\
\hline 4 & Voltage, V & 96-116 & $24-150$ & $\begin{array}{l}115- \\
135\end{array}$ & $96-560$ & $96-560$ & $\begin{array}{l}250- \\
700\end{array}$ & 380 & 380 & $\begin{array}{l}270- \\
425\end{array}$ & $72-120$ \\
\hline 5 & $\begin{array}{c}\text { Rated torque / } \\
\text { maximum } \\
\text { torque, } N * m\end{array}$ & $\begin{array}{l}80 / \\
185\end{array}$ & $\begin{array}{c}125 / 24 \\
0\end{array}$ & $\begin{array}{l}80 / \\
160\end{array}$ & $\begin{array}{c}13 / \\
45,96 \mathrm{~V}\end{array}$ & $\begin{array}{c}33,4 / 80 \\
, 96 \mathrm{~V}\end{array}$ & $\begin{array}{l}110- \\
370\end{array}$ & $\begin{array}{l}80 / \\
180\end{array}$ & $160 / 350$ & $120 / 300$ & $\begin{array}{l}80 / \\
160\end{array}$ \\
\hline 6 & $\begin{array}{c}\text { Rated } \\
\text { capacity / } \\
\text { maximum } \\
\text { capacity, kW }\end{array}$ & $\begin{array}{c}35 / \\
50\end{array}$ & $\begin{array}{l}45 / \\
100\end{array}$ & $\begin{array}{l}33 / \\
80\end{array}$ & $\begin{array}{l}13 / \\
24 ; \\
96 \mathrm{~V}\end{array}$ & $\begin{array}{c}21 / \\
40,7 \\
96 \mathrm{~V}\end{array}$ & $50-160$ & $25 / 50$ & $\begin{array}{l}50 / \\
90\end{array}$ & $\begin{array}{l}60 / \\
100\end{array}$ & $25 / 50$ \\
\hline 7 & $\begin{array}{l}\text { Rotational } \\
\text { speed, rpm }\end{array}$ & $\begin{array}{l}2400 / \\
2600\end{array}$ & $\begin{array}{c}2000 / \\
5500\end{array}$ & $\begin{array}{l}2000 / \\
6000\end{array}$ & $\begin{array}{l}3000 / \\
6000\end{array}$ & $\begin{array}{l}3000 / \\
6000\end{array}$ & $\begin{array}{l}2000 / \\
8000\end{array}$ & $\begin{array}{c}3000 \\
/ \\
6000\end{array}$ & $\begin{array}{l}3000 / \\
6000\end{array}$ & $\begin{array}{l}3000 / \\
7700\end{array}$ & $\begin{array}{c}3200 \\
/ \\
6000\end{array}$ \\
\hline 9 & Weight, kg & 43 & 12,3 & 9,3 & 12.3 & 29.8 & 24 & 40 & 64 & $\mathrm{n} / \mathrm{a}$ & 39 \\
\hline 10 & $\begin{array}{c}\text { Specific rated } \\
\text { capacity / } \\
\text { specific } \\
\text { maximum } \\
\text { capacity, } \\
\text { кW/kg }\end{array}$ & $\begin{array}{c}1,4 / 1,8 \\
6\end{array}$ & $3,8 / 8,1$ & $3,5 / 8,6$ & $1,1 / 2$ & $0,7 / 1,4$ & $2 / 6,7$ & $\begin{array}{c}0,63 / 1,2 \\
5\end{array}$ & $\begin{array}{l}0,8 / \\
1,4\end{array}$ & $\mathrm{n} / \mathrm{a}$ & $\begin{array}{c}0,64 / \\
1,3\end{array}$ \\
\hline 11 & $\begin{array}{l}\text { Overload } \\
\text { capacity } \\
\text { factor }\end{array}$ & 1,33 & 2,22 & 3,2 & 1,85 & 1.93 & 3,2 & 2 & 1,8 & 1,7 & 2 \\
\hline 12 & $\begin{array}{l}\text { Overload } \\
\text { rated torque } \\
\text { factor }\end{array}$ & 1,47 & 1,92 & 2 & 2,2 & 2.4 & 3,4 & 2,25 & 2,2 & 2,5 & 2,19 \\
\hline
\end{tabular}




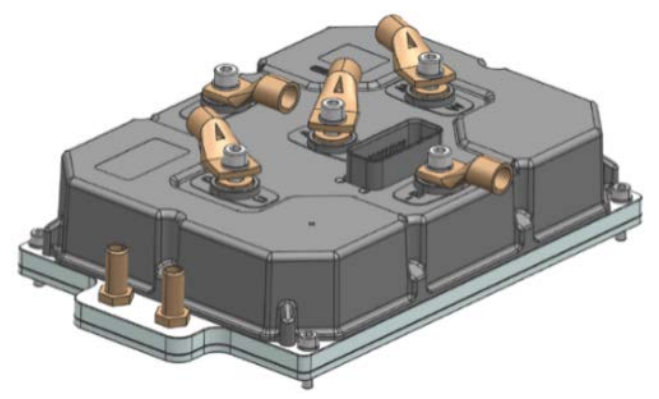

Fig. 2. General view of the power converter emDrive 500

\subsection{Energy storage device}

Based on the results of calculations of the energy consumption of the ATV, an energy storage device was selected Lithium Force battery. Battery specifications are shown in Table 2.

Table 2. Battery characteristics

\begin{tabular}{|l|l|}
\hline Characteristic & Value \\
\hline Rated voltage, $\mathrm{V}$ & 116,8 \\
\hline Rated battery capacity, $\mathrm{A} \cdot \mathrm{h}(\mathrm{kW} \cdot \mathrm{h})$ & $81(9,46)$ \\
\hline Working voltage range, $\mathrm{V}$ & $96-134,4$ \\
\hline Discharge rate, C & 4,3 \\
\hline Category temperature range, ${ }^{\circ} \mathrm{C}$ & \\
- recharge & $0 . .55$ \\
- discharge & $-20 . .55$ \\
\hline The life of battery, cycle & 1800 \\
\hline Weight, kg & 100 \\
\hline
\end{tabular}

\subsection{Traction drive cooling system}

For the cooling system of the developed ATV, a radiator installed on the PM 650 ATV was chosen (Figure 3). The choice is due to the unification of products of the enterprise "Russian Mechanics" and the calculations.

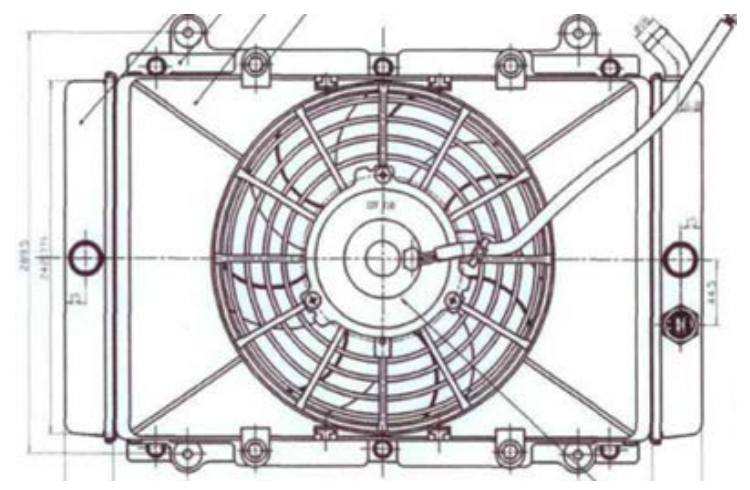

Fig. 3. Radiator for the PM 650 ATV 
The pump for the cooling system of the developed 4x4 ATV was chosen based on the calculations. The requirement to ensure the required flow at a given hydraulic resistance is met by 2 pumps:

$$
\begin{aligned}
& \text { - } \quad \text { Simaco C } 36 \text { DC-24V (Italy) [20] } \\
& \text { - } \quad \text { Marco UPX-C 12V (Germany) [21] }
\end{aligned}
$$

\section{Justification of the selected design diagrams of transmission components}

\subsection{Transfer case}

On an ATV with an electromechanical transmission, the decision was made to use a twostage transfer case with a chain drive and a lockable center differential, which allows achieving the following advantages:

- reduced resistance to movement of the ATV in a curve and, as a result, reduced energy losses

- rejection of the drive for connecting the front gearbox and, to a greater extent, the unification of the front and rear main gears, which leads to a simplified design

The view and section of the transfer case is shown in Figure 4.
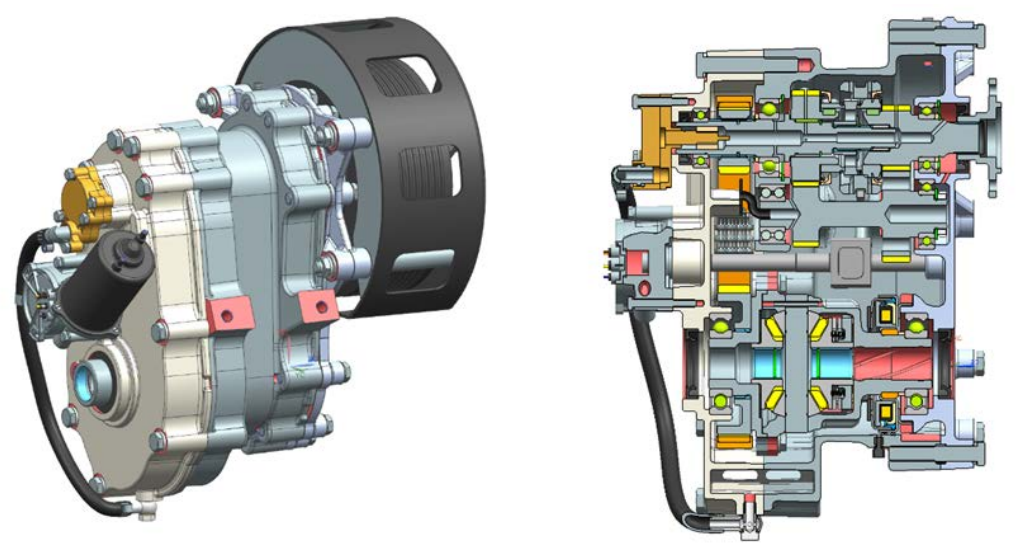

Fig. 4. The view and section of the transfer case

For each of the traction electric motor variants, thrust calculations were carried out, according to the results of which the product mobility indicators were determined.

The dynamic factor of the product was determined in accordance with the formula:

$$
D_{i}(\omega)=\left(\frac{M(\omega) \cdot U_{\mathrm{TC}-i} \cdot U_{m g} \cdot \eta}{r}-P_{w}\right) \frac{1}{m \cdot g},
$$

where $M(\omega)$ - the torque of the electric motor as a function of the angular speed of rotation of the rotor of the electric motor $\omega$,

$U_{T C-i}$ - gear ratio of the i-th gear in the transfer case;

$U_{m g}$ - final drive ratio;

$\eta=0,85$ - overall transmission efficiency;

$r$ - wheel rolling radius;

$P_{w}-$ air resistance force;

$m$ - gross ATV weight;

$g-$ acceleration of gravity. 
The force of air resistance depending on the vehicle speed $\mathrm{V}$ was calculated by the formula:

where $C_{x}$ - stream-lining coefficient;

$$
P_{w}(V)=C_{x} \cdot S \cdot \frac{\rho \cdot V^{2}}{2}
$$

$S$ - ATV mid-section area;

$\rho$ - air temperature.

In the calculations, the following parameter values were taken:

$C_{x}=0,7 ; S=1,506 \mathrm{~m}^{2} ; \rho=1,25 \mathrm{\kappa} \Gamma / \mathrm{M}^{3}$.

The gear ratios of the transmission units were selected during traction calculations based on the provision of the maximum speed in the top gear and the dynamic factor that ensures the overcoming of the maximum wheel adhesion to the lifting surface. The resulting gear ratios of the transmission units are presented in Table 3.

Table 1. Gear ratios of transmission unit.

\begin{tabular}{|l|c|}
\hline Transmission assembly & Gear ratios \\
\hline Transfer case & $\mathrm{U}_{\mathrm{TC} 1}=2,1$ \\
- high gear & $\mathrm{UT}_{\mathrm{TC} 2}=5,04$ \\
- creeper gear & 3,7 \\
\hline Main gear & . \\
\hline
\end{tabular}

The results of calculating the dynamic factor are shown in Figures 5, 6, 7.

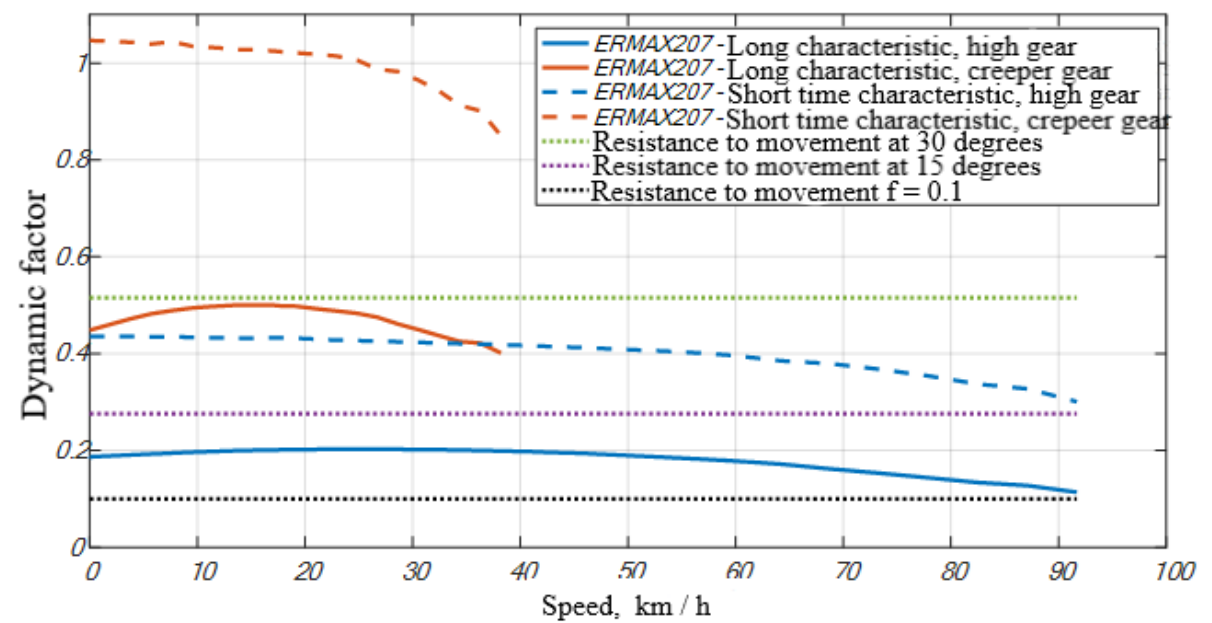

Fig. 5. The dynamic factor of the ATV with Emrax 208 


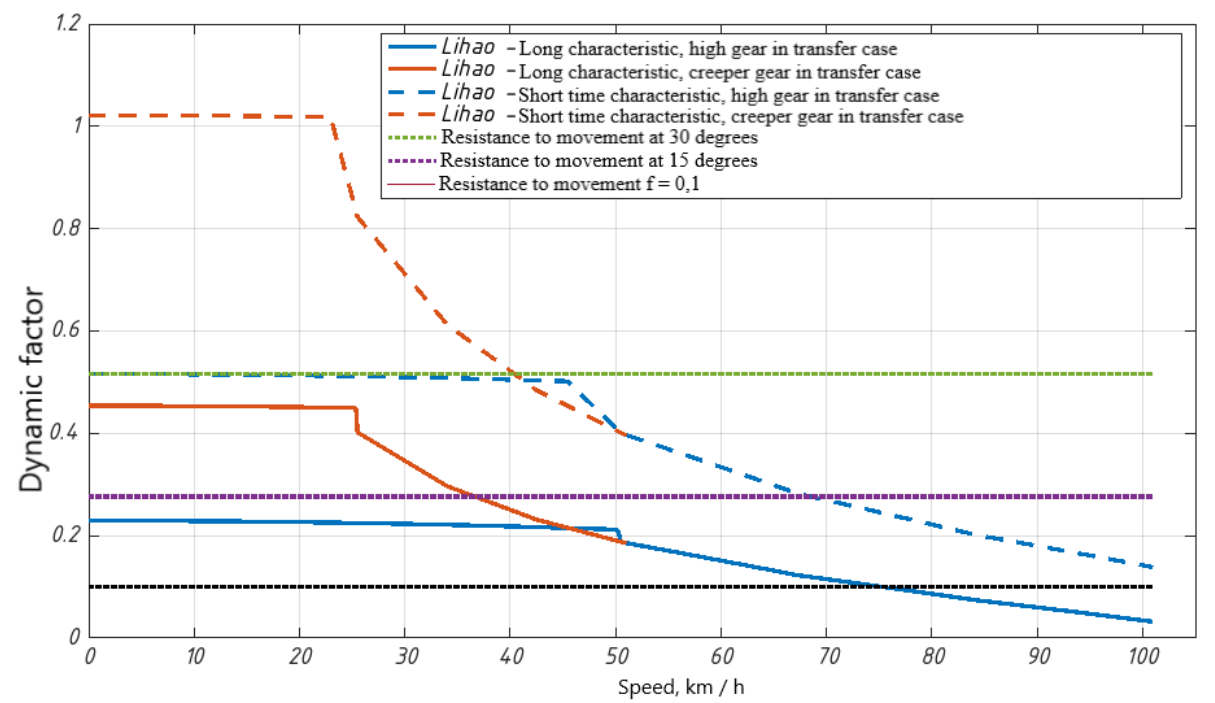

Fig. 6. The dynamic factor of the ATV with Lihao 260J

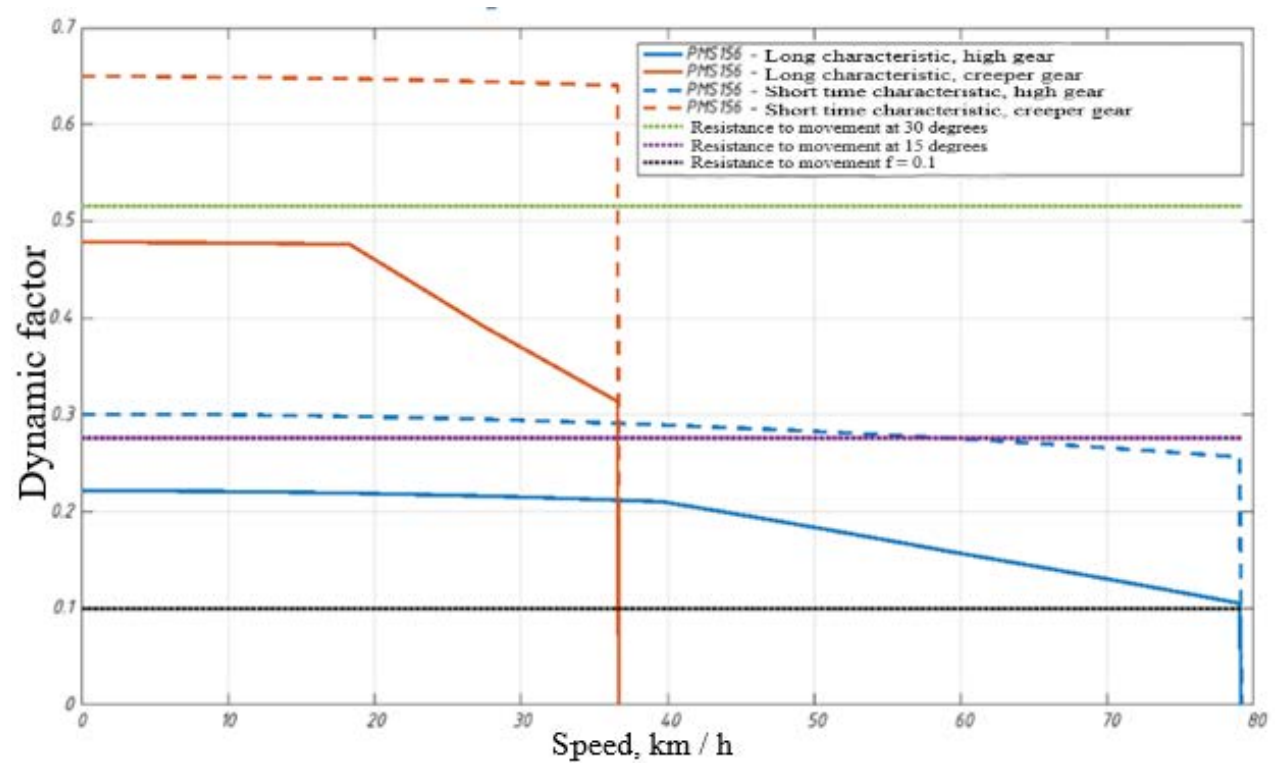

Fig. 7. The dynamic factor of the ATV with PMS156

Traction and dynamic calculations showed that the ATV equipped with the PMS156W is significantly inferior to the other models under consideration in terms of the value of the maximum dynamic factor, which means in terms of acceleration time to maximum speed and, if possible, overcoming hills. The dynamic characteristics of the ATV with the Lihao 260J and Emrax 208 are similar, but the characteristics of the Lihao 260J are given for a rated voltage of $380 \mathrm{~V}$, the use of which on board a vehicle of this class is unsafe. Also Lihao 260J with characteristics similar to Emrax 207 is significantly inferior to the latter in terms of weight.

A review of analogs and a comparative analysis showed that Emrax 208 is the most suitable for use in the traction electric drive of an all-terrain vehicle. 
Analyzing the graph of changes in the dynamic factor (Figure 5), the following conclusions can be drawn:

1) the maximum travel speed of the ATV on an asphalt concrete road (rolling resistance coefficient $\mathrm{f}=0,018)-90 \mathrm{~km} / \mathrm{h}$;

2) the maximum speed of the ATV on a dirt road in muddy, sand or snow virgin land $(\mathrm{f}=0,2 . .0,4)-$ not less than $30 \mathrm{~km} / \mathrm{h}$;

3 ) the maximum angle of elevation of the ATV of full weight on asphalt concrete pavement is not less than $35 \square$ (when the electric motor is operating at a short-term characteristic).

The characteristics of the developed transfer case are shown in table 4.

Table 4. Transfer case characteristics

\begin{tabular}{|l|l|}
\hline \multicolumn{1}{|c|}{ Type } & \multicolumn{1}{c|}{ Twin-shaft } \\
\hline Number of steps & 2 \\
\hline Reduction speed ratio & 5,04 \\
\hline Overdrive speed ratio & 2,16 \\
\hline Cross-axle differential & Yes, blockable \\
\hline Front axle attachment module & No \\
\hline Maximum input torque, Nm & 240 \\
\hline Weight, kg & 28,9 \\
\hline
\end{tabular}

\subsection{Main gear}

In the process of developing the main gears, a comparative analysis of the main gears of mechanical ATVs was carried out. Technical characteristics of the main gears of ATVs of analogs are presented in Table 5.

Based on the technical analysis of the data shown in Table 6, the following main trends in the development of the main gears of ATVs can be distinguished:

- in all considered cases, except for the PM 650 all-terrain vehicle, a bevel main gear with a straight forged tooth is used;

- the average gear ratio of the main gear is 3.68;

- the front gear can be disabled;

- the differential in the rear final drive is absent in all cases considered.

Mathematical modeling was carried out, during which the turning trajectories of ATVs with the following kinematic transmission schemes were obtained:

1) $4 \times 4$, front and rear differentials are locked;

2) $4 \times 4$, front and rear differentials are not locked;

3) $4 \times 2$, front and rear differentials locked;

4) $4 \times 4$, front differential is not locked, rear differential is locked;

5) $4 \times 2$, front differential is not locked, rear differential is locked.

The maximum steering angle was 30 degrees.

The trajectories of ATVs with the considered kinematic schemes are shown in Figure 8. The least turning radius are presented in Table 6.

Table 6 shows that the presence of a differential in the rear gearboxes reduces the least turning radius by an average of $20 \%$. 
Table 5. Technical characteristics of the main gears of ATVs analogs

\begin{tabular}{|c|c|c|c|c|c|c|}
\hline № & Parameter & $\begin{array}{c}\text { BRP } \\
\text { Outlander } \\
\max 570 \\
\text { DPS }\end{array}$ & $\begin{array}{c}\text { Yamaha } \\
\text { Grizzly } 700\end{array}$ & $\begin{array}{c}\text { Polaris } \\
\text { Sportsman } \\
\text { Touring } 570\end{array}$ & PM 650-2 & $\begin{array}{c}\text { Developed by } \\
\text { ATV }\end{array}$ \\
\hline 1 & $\begin{array}{l}\text { Full weight of the } \\
\text { vehicle, } \mathrm{kg}\end{array}$ & 659 & 525 & 613 & 655 & 655 \\
\hline 2 & Gear ratio & 3,6 & 3,66 & 3,81 & 3,66 & 3,7 \\
\hline 3 & $\begin{array}{c}\text { Gear type / } \\
\text { Preparation method }\end{array}$ & $\begin{array}{l}\text { Spur gear/ } \\
\text { Stamping }\end{array}$ & $\begin{array}{l}\text { Spur gear / } \\
\text { Stamping }\end{array}$ & $\begin{array}{l}\text { Spur gear / } \\
\text { Stamping }\end{array}$ & \begin{tabular}{|c|}
$\begin{array}{c}\text { With circular } \\
\text { tooth/ } \\
\text { Milling }\end{array}$ \\
\end{tabular} & $\begin{array}{l}\text { With circular } \\
\text { tooth/ Milling }\end{array}$ \\
\hline 4 & Front axle drive & $\begin{array}{l}\text { Pluggable, } \\
\text { in the } \\
\text { transfer case }\end{array}$ & $\begin{array}{l}\text { Pluggable, in } \\
\text { gearbox }\end{array}$ & $\begin{array}{c}\text { Connects } \\
\text { simultaneously } \\
\text { with blocking }\end{array}$ & $\begin{array}{c}\text { Pluggable, in } \\
\text { gearbox }\end{array}$ & $\begin{array}{l}\text { Pluggable, } \\
\text { in gearbox }\end{array}$ \\
\hline 5 & $\begin{array}{c}\text { Front axle } \\
\text { differential, } \\
\text { blocking type }\end{array}$ & $\begin{array}{l}\text { Viscous } \\
\text { coupling } \\
\text { Visco-lok }\end{array}$ & $\begin{array}{l}\text { Three- } \\
\text { position } \\
\text { motor }\end{array}$ & $\begin{array}{c}\text { Connects } \\
\text { simultaneously } \\
\text { with blocking }\end{array}$ & $\begin{array}{l}\text { Three- } \\
\text { position } \\
\text { motor }\end{array}$ & Electromagnet \\
\hline 6 & $\begin{array}{c}\text { Rear axle } \\
\text { differential }\end{array}$ & No & No & No & No & Yes \\
\hline 7 & Automatic blocking & Yes & No & Yes & No & Possibly \\
\hline 8 & $\begin{array}{l}\text { Automatic } \\
\text { connection of the } \\
\text { front axle }\end{array}$ & No & No & Yes & No & Possibly \\
\hline 9 & $\begin{array}{l}\text { Front gearbox } \\
\text { weight (without } \\
\text { oil), kg }\end{array}$ & - & 6,23 & 6,56 & 8 & 11,5 \\
\hline 10 & $\begin{array}{l}\text { Rear gearbox } \\
\text { weight (without } \\
\text { oil), } \mathrm{kg}\end{array}$ & \multicolumn{3}{|c|}{$\sim 5$} & 6 & 9,8 \\
\hline
\end{tabular}

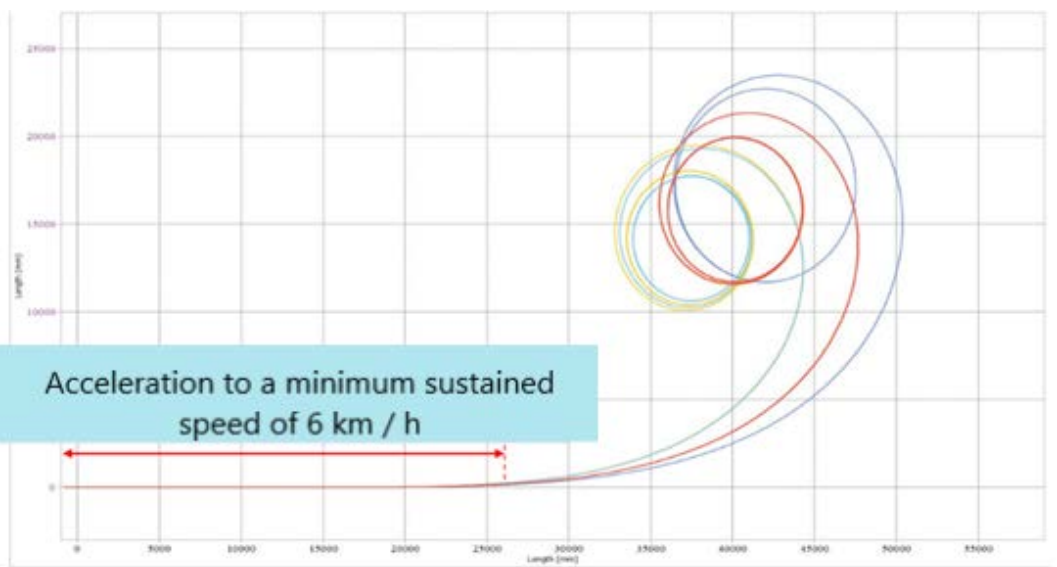

Fig. 8. The trajectory of ATVs motion with the considered kinematic schemes. 
Table 6. Least turning radius

\begin{tabular}{|c|c|c|}
\hline The schema number & The color of the trajectory & Least turning radius, $m$ \\
\hline 1 & & 5,64 \\
\hline 2 & & 3,85 \\
\hline 3 & & 3,51 \\
\hline 4 & & 4,44 \\
\hline 5 & & 4,40 \\
\hline
\end{tabular}

In the developed family of drive axles, a differential lock is provided for both the front and rear gearboxes of the vehicle being developed. The presence of a differential in the rear gearboxes will allow:

1) reduce the least turning radius of the ATV;

2) will provide greater driving stability and better handling at high speeds;

3) to unify the front and rear gears to a greater extent and reduce the manufacturing cost;

4) reduce energy loss and fuel consumption when turning the ATV.

The developed main gears of the front and rear axles are single-stage conical and have a high level of unification within the family.

The view and section of the main gear are shown in Figure 9.
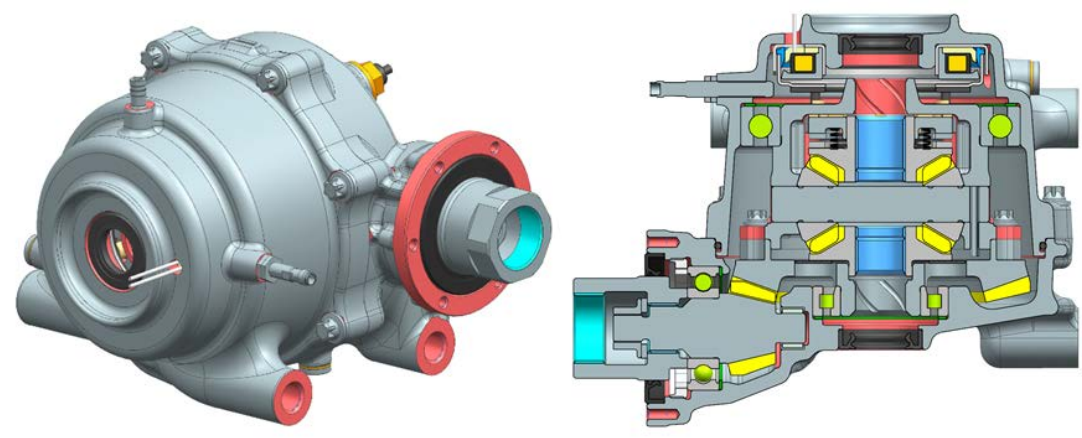

Fig. 9. The view and section of the main gear.

The developed main gear is single-stage, bevel with a gear ratio of 3.7 , has a cross-axle differential with the ability to lock. The mass of the developed main gear is $11.3 \mathrm{~kg}$.

\section{Conclusion}

As a result of the comparative tests and the constructed mathematical models, the following components were selected to optimize the operation of the ATV with an electromechanical transmission: EMRAX 208 electric motor, emDrive 500 power converter, traction motor cooling system, transfer case with center differential and both front and rear main gears.

Due to the selected components, it was possible to achieve a decrease in energy loss, unify the design, reduce the angle of rotation by $20 \%$, and install an electric motor of the required power. This made it possible to obtain an ATV with an electromechanical transmission, which is not inferior to an ATV with a manual transmission. 


\section{References}

1. Larin, VV Theory of motion of all-wheel drive wheeled machines: textbook / VV Larin. M.: Publishing house of MSTU im. N.E.Bauman, 2010. - 391. Yaskevich, Z. Leading bridges / Z. Yaskevich -Moscow: Mechanical Engineering, 1985. -595 p.

2. Design of car transmissions: Handbook / Under total. ed. A.I. Grishkevich. - M.: Mechanical Engineering, 1984, - 272 p.

3. Modeling of vehicle systems: Textbook / M.M. Zhileikin, G.O. Kotiev. - M.: Publishing house of MSTU im. N.E. Bauman, 2017.

4. Sosnin D.A. Electrical, electronic and autotronic equipment for cars (Avtotronika-3): Textbook for universities. M.: SOLON-PRESS, 2010, $384 \mathrm{p}$.

5. Smirnov Yu.A., Mukhanov A.V. Electronic and microprocessor control systems for cars: a textbook. - SPb.: Publishing house "Lan", 2012. - 624 p.: ill.

6. Fundamentals of electric drive: textbook / A.B. Krasovsky. - Moscow: Publishing house of MSTU im. N.E. Bauman, 2015. - 405, [3] p.: ill.

7. Reshetov DN, Machine parts: A textbook for students of mechanical engineering universities. - 4th ed., Rev. and add. - M.: Mechanical Engineering, 1989.—496 p .: ill.

8. GOST R 51815-2001. Quadricycles. General technical requirements: introduced. 01.07.2002. - M.: Publishing house of standards, 2001. - $12 \mathrm{p}$.

9. R 52008-2003. Four-wheeled off-road motor vehicles. General technical requirements: introduced. 01.01.2004. - M.: Publishing house of standards, 2003.—19

10. V.V., Pozdeev A.V., Diakov A.S. Research and testing complex for analysis of vehicle suspension units // Procedia Engineering. 2015. Vol. 129. P. 465-470. DOI: 10.1016/j.proeng.2015.12.15

11. Kotiev G.O., Padalkin B.V., Kartashov A.B., Dyakov A.S. Designs and development of Russian scientific schools in the field of cross-country ground vehicles building // ARPN Journal of Engineering and Applied Sciences. 2017. Vol. 1 № 4. P. 1064-1071.

12. Kotiev G.O., Diakov A.S. Advanced development and testing of off-road vehicle // DEStech Transactions on COMPUTER SCIENCE and ENGINEERING. 2017 2nd International Conference on Computer, Mechatronics and Electronic Engineering $\begin{array}{lllll}(C M E E & 2017) & \text { pp. 464-467. ISBN: 978-1-60595-532-2. DOI }\end{array}$ 10.12783/dtcse/cmee2017/20021.

13. Diakov A.S., Kotiev G.O. Establishment of production of special wheel and track technology for extreme natural-climate conditions of the Arctic // MATEC Web of Conferences Volume 224, 30 October 2018, article number 02096 DOI: $10.1051 /$ matecconf $/ 201822402096$

14. Diakov A.S., Novikov V.V., Pozdeev A.V. The main directions of the development of snowmobiles in the Russian Federation// MATEC Web of Conferences Volume 224, 30 October 2018, article number 02080 DOI: 10.1051/matecconf/201822402080

15. D.A. Chumakov, K.V. Chernyshov, V.V. Novikov, A.S. Diakov and A.S. Suchenina. Mathematical model of motor vehicle air suspension with a combined damping system. IOP Conf. Series: Journal of Physics: Conf. Series 1177 (2019) 012049. DOI:10.1088/1742-6596/1177/1/012049.

16. V.E. Klubnichkin, A.S. Dyakov, E.E. Klubnichkin, A.Yu. Zakharov, U.Sh. Vakhidov, A.S. Suchenina and I.V. Basmanov. Experimental evaluation of speed and brake properties of domestic and foreign made utility terrain vehicles. IOP Conf. Series: Journal of Physics: Conf. Series 1177 (2019) 012048. DOI:10.1088/1742-6596/1177/1/012048.

17. V.E. Klubnichkin, A.S. Dyakov, E.E. Klubnichkin, A.Yu. Zakharov, U. Sh. Vakhidov, A.S. Suchenina and I.V. Basmanov. Experimental evaluation of stability and controllability of domestic and foreign made utility terrain vehicles. IOP Conf. Series: 
Journal of Physics: Conf. Series 1177 (2019) 012045. DOI:10.1088/17426596/1177/1/012045.

18. https://emrax.com/e-motors/emrax-208/

19. https://www.emdrive-mobility.com/portfolio/emdrive-500/

20. https://www.simacosrl.it/prodotti/dc-24v/

21. https://marco-pumps.shop/marco-upx-c-12v-chem-pump-15-1-min-ss-aisi-316-24-volt$\underline{16404113 /}$ 